\title{
The sustainability level of rice seed breeding business: individual characteristics and external support aspects
}

\author{
Atang Safei ${ }^{1 *}$, Siti Amanah ${ }^{2}$, and Anna Fatchiya ${ }^{2}$ \\ ${ }^{1}$ West Java Assessment Institute for Agricultural Technology, Ministry of Agriculture, Indonesia \\ ${ }^{2}$ Department of Communication Science and Community Development, IPB University, Indonesia
}

\begin{abstract}
The business sustainability of rice seed breeding in the breeder groups is very important to provide qualified rice seeds, improve the farmer's income and welfare, and become the indicator of the success of the program. The study aimed to analyze the level of sustainability of the rice seed breeding business and the influence of the level of support from the government, private sectors and community leaders on the level of sustainability of the business. Data were collected from 112 farmers in Majalengka from December 2020 to January 2021. The data were analyzed by Partial Least Square (PLS-Path Modeling) using SmartPLS3. The results showed that the sustainability level of the rice seed breeding business in the aspect of production and business profits was included in the high category. Production and profits of rice seed breeding business are higher than consumption rice farming. The level of private support and community leaders have a significant effect on the sustainability level of the rice seed breeding business. The government provides farmer protection programs, but the farmers have not used them optimally. The involvement of community leaders can increase the sustainability of the breeding business in terms of production, market guarantee and business profits.
\end{abstract}

\section{Introduction}

Excellent quality rice seeds can increase farmers' productivity and income [1] but their availability and application is still limited. The Ministry of Agriculture has produced more than 150 high-yielding varieties of rice but only a small number have grown by farmers [2]. In 2019, the use of certified seeds only reached 52,84\% [3]. This is the impact of the limited number of seed breeders who produced certified seeds in the field. The production of certified rice seeds in West Java has only reached 31,345.65 tons of all 51,263 tons demanded seeds [4][5]. The availability of certified rice seeds can be performed through the development of rice seed breeding. The rice seed breeding business deserves to be developed because it produces more profits than the rice business [6][7]. Although, the process of producing certified rice seeds takes additional activities such as seed certification process, rouging and post-harvest handling.

\footnotetext{
* Corresponding author: atangsafei@apps.ipb.ac.id
} 
The success of agricultural business can be supported by human resources of farmers, policies and infrastructure support from the government, product marketing [8], capital [9], provision of superior seeds, availability of fertilizers, marketing institutions related to the role of service delivery government [10]. The availability of certified superior seeds can be established by increasing the number of breeders [11]. In 2015 the Government of Indonesia developed a rice seed breeding business through the Desa Mandiri Benih (Seeds Selfsufficiency Village) program. The government provides assistance in the form of a package consisting of production facilities, complementary facilities, warehouses, and training in the rice seed breeding business. Providing aid without optimal assistance can lead to dependence [12]. Therefore, assistance must be carried out until the breeder farmers have achieved independence and sustainability in the rice seed breeding business.

The concept of sustainability is not clearly defined regarding its criteria and indicators [13]. Sustainability can cover aspects such as economic business (profit), human social life (people), and natural ecological environment (planet) [14]. Aspects of business sustainability can be measured based on indicators of production, sales capacity, and profits [15], stability and profit, income distribution, marketing capabilities, and expenses [16], production, partnerships, and profits [17]. The level of sustainability of the rice seed breeding business program resides in the quality of human resources, as well as the capital [18]. Therefore, external support from the government, private companies, and community leaders play important roles in achieving the sustainability of the rice seed breeding business.

The government has a role in facilitating the production process and distribution of seeds of new superior rice varieties through marketing, mentoring, and providing seed subsidies. Farmer entrepreneurship can be increased through trust in the government in facilitating rice seed breeding business to become self-suffiency. The facilitation can be obtained through intensive and sustainable communication and assistance [19].

The research revealed that the reasons why farmers continue their seed breeding business are income, number of family dependents, land area, and production results [20]. The determinants of the success of the rice seed breeding business are the low selling price of seeds, the absence of market guarantees [21], capital, seed knowledge, market access, and efficiency in the use of production factors [22]. The pattern of partnerships with private companies that do not work perfectly can affect the technical efficiency of rice seed breeding business [22].

Based on these findings, it can be seen that the research on the role of external support such as the government, the private companies and community leaders in supporting the sustainability of the rice seed breeding business is still limited. Therefore, the purpose of this study were 1) to analyze the level of sustainability of the rice seed breeding business and 2) to analyze the influence of the level of support from the government, private companies, and community leaders on the sustainability of the rice seed breeding business.

\section{Material and methods}

\subsection{Research method}

This research is quantitative study with the type of explanatory research. Data collection through the survey method was carried out in three sub-districts, namely Jatitujuh, Kertajati, and Sukahaji, Majalengka District from December 2020 to January 2021. The study location was determined purposively, namely Majalengka Regency where the first winning farmer group at the national level was Desa Mandiri Benih (Seeds Self-sufficiency Village). The farmer group has been successful in sustainable rice seed breeding business. The research population is rice seed breeder farmers in Majalengka. Respondents amounted to 112 people 
who were determined through the census method as the unit of analysis. They were 48 farmers Gangsa I breeder group, 30 farmers Guna Tani breeder group and 34 farmers Sukamaju II breeder group.

Primary data were collected through interviews using a structured questionnaire as a research instrument. The results of the validity test using Pearson Product Moment obtained the value of $r$ count of all question items $>r$ table (0.396) which is between $0.412-0.888$ the value of the reliability test on the independent variable is 0.940 and the variable of sustainability of seed breeding business is 0.748 . This means that the research instrument is feasible to use. To obtain more detailed data and information regarding rice seed breeding, in-depth interviews were conducted toward 1) Extension workers from the Food Security, Agriculture and Fisheries Service of Majalengka Regency; 2) Extension workers, researchers, and research and engineering technicians from the West Java Assessment Institute of the Agricultural Technology, as well as 3) The heads and administrators of the three breeder groups.

\subsection{Data processing}

The primary data collected were independent variables in the form of individual characteristics of farmers $\left(\mathrm{X}_{1}\right)$, level of government support $\left(\mathrm{X}_{2}\right)$, level of private companies support $\left(\mathrm{X}_{3}\right)$, level of community leader support $\left(\mathrm{X}_{4}\right)$ and dependent variables, namely the level of business sustainability (Y). The business sustainability level is the sustainability of farming in the aspects of production, sales capacity and business profits [15] as well as aspects of production, partnerships and profits [17]. In this study, the criteria and indicators of the level of business sustainability used aspects such as production, market guarantees and business profits. The production aspect was measured by the consistency or increase in rice seed production from consumption farming. Aspects of market guarentee were measured based on partnerships and marketing. Aspects of business profit were indicated by breeding rice seeds using low farming costs, higher product prices, and increasing income from consumption rice farming. All answers in the questionnaire were based on a Likert scale into four categories, namely very low (1), low (2), moderate (3) and high (4).

The first purpose of the research was to analyze the sustainability level of the rice seed breeding business which was measured through three sub-variables was answered through descriptive statistical analysis. Descriptive statistics to analyze data by describing the data that has been collected. The second research objective was to analyze the influence of support from the government, private companies and community leaders on the level of sustainability of the business, obtained through analysis using Partial Least Square (PLS-Path Modeling) with the SmartPLS3 application. The measurement model (outer model) in Smart PLS was used to assess the construct validity and reliability of the variables through an algorithmic literacy process to obtain the measurement model parameters. The measurement model can specify the relationship between latent variables and their indicators. For confirmatory research, the parameters of convergent validity assessed are loading factor $>0.7$ (outer loading), Average Variance Extracted (AVE) $>0.5$. The reliability test was conducted to prove the accuracy, consistency and accuracy of the instrument in measuring the construct. Reliability is assessed based on the composite reliability value, which is $>0.7$. The reliability test was strengthened by the Cronbach Alpha value $>0.7$ for all constructs.

The structural model (inner model) was used to assess the strength of the estimate between latent variables so that the strength of the model can be known. The structural model analysis was carried out through the bootstrapping process. The structural model assessment used the $\mathrm{R}^{2}$ value to measure the level of variation in individual characteristic variables and external support for the level of business sustainability. The $\mathrm{R}^{2}$ value of 0.365 means that the model was included in the moderate category [23]. 


\section{Results and discussion}

\subsection{Breeder profiles}

The majority of breeder farmers $(83 \%)$ were in the productive age. They have the potential to increase productivity and sustainability of the seed breeding business because they can accept and implement innovations of rice seed breeding. Physical abilities are needed in the process of seeds breeding, such as rice cultivation, seed certification, roguing, and postharvest handling. Characteristics of farmers that can become obstacles in the sustainability of the seed breeding business are low experience, formal education, non-formal education, degree cosmopolitan and farmers' land area (Table 1).

Table 1. Comparison of individual characteristics of breeder farmers in the three study districts in Majalangka Regency, 2021

\begin{tabular}{|c|c|c|c|c|c|c|}
\hline \multirow{3}{*}{$\begin{array}{c}\text { Individual } \\
\text { Characteristics }\end{array}$} & \multirow{3}{*}{ Category } & \multicolumn{3}{|c|}{ Sub-districts } & \multirow{3}{*}{$\begin{array}{l}\text { Total } \\
\mathrm{n}=112\end{array}$} & \multirow{3}{*}{$\begin{array}{l}\text { Kruskal } \\
\text { Wallis } \\
\text { difference } \\
\text { test }\end{array}$} \\
\hline & & Jatitujuh & Kertajati & Sukahaji & & \\
\hline & & $\begin{array}{c}\mathrm{n}=48 \\
\%\end{array}$ & $\begin{array}{c}\mathrm{n}=34 \\
\%\end{array}$ & $\begin{array}{c}\mathrm{n}=30 \\
\%\end{array}$ & & \\
\hline \multirow{4}{*}{$\begin{array}{l}\text { Age }(\text { years old }) \\
\text { Average }=47.7\end{array}$} & Adolescent (12-17) & 0 & 0 & 0 & 0 & \multirow{4}{*}{0.126} \\
\hline & Early adult (18-30) & 4.2 & 14.7 & 3.3 & 7.2 & \\
\hline & Intermediary (31-60) & 89.6 & 73.5 & 83.3 & 83.0 & \\
\hline & Late adult $(>60)$ & 6.2 & 11.8 & 13.4 & 9.8 & \\
\hline \multirow{4}{*}{$\begin{array}{l}\text { Breeding } \\
\text { experience } \\
\text { (years) } \\
\text { Average }=3.5\end{array}$} & Very low $(\leq 2)$ & 14.6 & 61.8 & 16.7 & 29.5 & \multirow{4}{*}{$0.000 *$} \\
\hline & Low (3-4) & 33.3 & 20.6 & 80.0 & 42.0 & \\
\hline & Intermediate (5-6) & 41.7 & 8.8 & 0 & 23.2 & \\
\hline & $\operatorname{High}(\geq 7)$ & 10.4 & 8.8 & 3.3 & 5.3 & \\
\hline \multirow{4}{*}{ 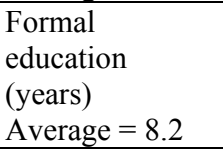 } & Very low $(\leq 6)$ & 27.1 & 64.7 & 83.3 & 53.5 & \multirow{4}{*}{$0.000 *$} \\
\hline & Low (7-9) & 18.7 & 23.5 & 13.4 & 18.7 & \\
\hline & Intermediate $(10-12)$ & 50.0 & 11.8 & 3.3 & 26.0 & \\
\hline & $\operatorname{High}(\geq 13)$ & 4.2 & 0 & 0 & 1.8 & \\
\hline \multirow{4}{*}{$\begin{array}{l}\text { Non formal } \\
\text { education } \\
\text { (times) } \\
\text { Average }=3.2 \\
\end{array}$} & Very low $(\leq 2)$ & 62.5 & 94.2 & 40.0 & 50.9 & \multirow{4}{*}{$0.000 *$} \\
\hline & Low $(3-5)$ & 25.0 & 2.9 & 50.0 & 40.2 & \\
\hline & Intermediate (6-8) & 2.1 & 0 & 0 & 1.8 & \\
\hline & $\operatorname{High}(>8)$ & 10.4 & 0 & 10.0 & 7.1 & \\
\hline \multirow{4}{*}{$\begin{array}{l}\text { Cosmopolitan } \\
\text { level (score) } \\
\text { Average }=14.0\end{array}$} & Very low $(\leq 12)$ & 37.5 & 52.9 & 43.3 & 43.7 & \multirow{4}{*}{$0.045^{*}$} \\
\hline & Low (13-25) & 29.2 & 44.2 & 36.7 & 35.7 & \\
\hline & Intermediate (26-38) & 31.2 & 2.9 & 13.3 & 17.9 & \\
\hline & High $(>38)$ & 2.1 & 0 & 6.7 & 2.7 & \\
\hline \multirow{4}{*}{$\begin{array}{l}\text { Land area } \\
\text { (hectare) } \\
\text { Average }=0.87\end{array}$} & Very narrow $(<0.38)$ & 10.4 & 2.9 & 53.3 & 19.6 & \multirow{4}{*}{$0.000 *$} \\
\hline & Narrow $(0.382-0.75)$ & 22.9 & 52.9 & 30.0 & 34.0 & \\
\hline & Intermediate $(0.75-1.12)$ & 25.0 & 20.6 & 10.0 & 19.6 & \\
\hline & Wide $(>1.12)$ & 41.7 & 23.6 & 6.7 & 26.8 & \\
\hline
\end{tabular}

The breeding experience of the breeder farmers was in a low category. Farmers had no experience with different conditions in the seed production process, such as not passing certification or seed production cannot be sold. Farmers were not accustomed to determining the type and quantity of seeds, marketing strategies, and solving problems such as the availability of capital for planting rice in the following season. The average education of farmers has not reached junior high school. People with higher education prefered to work in other sectors such as trade and industry because they were considered more promising. Farmers only receive non-formal education during seed Desa Mandiri Benih program such as the Rice Seed Production Field School, integrated pest control training and planting using a rice transplanter. According to [24], the non-formal education of farmers is low due to the 
lack of training and extension activities carried out by the government. The training participants usually are farmer group leaders, administrators or members who are successful in farming. They do not follow-up the training, so the topics of the training unspread to others.

There were $79.4 \%$ of farmers had a degree cosmopolitan in the very low and low categories. There was assistance from the government where farmers get information from Agricultural Extention Center, the Department of Food Security, Agriculture and Fisheries of Majalengka Regency, Center for Supervision and Certification of Food Plant and Horticultural Seeds and West Java Assessment Institute of Agricultural Technology. Breeder farmers were less open to information and activities outside the area. They prefer to use their time to work in the fields and assumed that going outside the area will cost more money to spend. Farmers' land area was relatively distributed evenly from very narrow to wide. The narrow area of rice fields can be an obstacle in managing a business [25]. Farmers who have a narrow land area must join with others, because the minimum land area requirement in the seed certification process is 2 ha. Some farmers rent land over 1 ha for breeding business because they already have good experience in the seed breeding business. Land ownership was related to a person's innovative nature. Farmers who have large areas of land are relatively more responsive to innovations [26].

\subsection{Governmental, private companies, and community leader supports in the sustainability of rice seed breeding business}

There were significant differences between breeders' perceptions of the level of external support in the three research locations. The Gangsa I farmer group had the highest production capacity so that it gets more attention from various parties to collaborate. Perceptions of breeders at the level of support from the government, private companies and community leaders are in the medium category (Table 2).

Table 2. Comparison of the level of external support in the three study sub-districts in Majalengka Regency, 2021

\begin{tabular}{|c|c|c|c|c|c|c|}
\hline \multirow{3}{*}{ External Support } & \multirow{3}{*}{ Category } & \multicolumn{3}{|c|}{ Sub district } & \multirow{3}{*}{$\begin{array}{c}\text { Total } \\
\mathrm{n}=112 \\
\%\end{array}$} & \multirow{3}{*}{$\begin{array}{l}\text { Kruskal } \\
\text { Wallis } \\
\text { difference } \\
\text { test }\end{array}$} \\
\hline & & Jatitujuh & Kertajati & Sukahaji & & \\
\hline & & $\begin{array}{c}\mathrm{n}=48 \\
\%\end{array}$ & $\begin{array}{c}\mathrm{n}=34 \\
\%\end{array}$ & $\begin{array}{c}\mathrm{n}=30 \\
\%\end{array}$ & & \\
\hline \multirow{4}{*}{$\begin{array}{l}\text { Government support } \\
\text { level (score) } \\
\text { Average }=50.89\end{array}$} & Very low & 0 & 20.6 & 0 & 6.2 & \multirow{4}{*}{$0.001 *$} \\
\hline & Low & 33.3 & 47.0 & 36.7 & 36.6 & \\
\hline & Intermediate & 66.7 & 26.5 & 56.7 & 53.6 & \\
\hline & High & 0 & 5.9 & 6.6 & 3.6 & \\
\hline \multirow{4}{*}{$\begin{array}{l}\text { Private companies } \\
\text { support level (score) } \\
\text { Average }=65.48\end{array}$} & Very low & 0 & 5.9 & 0 & 1.8 & \multirow{4}{*}{$0.000 *$} \\
\hline & Low & 12.5 & 17.6 & 20.0 & 16.1 & \\
\hline & Intermediate & 52.1 & 76.5 & 80.0 & 67.0 & \\
\hline & High & 35.4 & 0 & 0 & 15.1 & \\
\hline \multirow{4}{*}{$\begin{array}{l}\text { Community leaders } \\
\text { support level (score) } \\
\text { Average }=47.97\end{array}$} & Very low & 2.1 & 41.2 & 16.7 & 17.8 & \multirow{4}{*}{$0.000^{*}$} \\
\hline & Low & 16.7 & 52.9 & 23.3 & 29.5 & \\
\hline & Intermediate & 54.1 & 5.9 & 60.0 & 41.1 & \\
\hline & High & 27.1 & 0 & 0 & 11.6 & \\
\hline
\end{tabular}

Note: Index score: very low $<25$; low 26-50; intermediate 51-75; high $>75$

**)Very significantly different at $\leq 0.01$

In encouraging the sustainability of the rice seed breeding business, the government protected farmers against the risk of crop failure through agricultural insurance, seed subsidies, provision of business capital, field assistance and facility improvement of seed breeding activities to contribute to village development. In the Desa Mandiri Benih program, 
the government assisted for seed breeding production facilities such as drying floors, storage warehouses and seed cleaners. Intensive assistance was carried out during the intensive program period. Assistance in increasing farmers' access to markets, technology and capital. However, the intensity of assistance from the government decreased after the end of program.

The government provided farmer protection through rice farming insurance $(A U T P)$. Rice farming insurance provided compensation of IDR 6,000,000 per hectare if farmers experience crop failure due to flooding, drought or pest and disease attacks. However, the interest of farmers in this program was low because farmers feel that AUTP compensation was too small to compensate for losses with a minimum percentage of damage of $75 \%$, which was rarely and the disbursement process takes time [27].

The government provides newly released rice source seeds of new superior varieties seeds for breeders, thereby accelerating the application of new varieties at the field level. The government cooperates with breeders to meet the needs of the seed subsidy program. The government increases the business capital of farmers through the People's Business Credit $(K U R)$. Farmers underutilize of $K U R$ because of the complicated requirements. The village government also supports seed breeding business through the development of farm roads and irrigation. However, the village government has not specifically allocated a budget for seed breeding development.

Breeder farmer groups cooperated with the private companies and farmer groups. They cooperated in purchasing, seeds marketing, and piloting innovations at the field level. This collaboration is carried out either with contract or without contract. Farmers had easier access to production inputs, capital, network expansion and marketing certainty, and also institutional capacity building and human resources [28]. The cooperation between farmer groups and the private companies had not been continuous so that the prices offered to farmers can vary and cooperation can stop at any time without any sanctions.

Bredders' perceptions of the level of support from community leaders for the sustainability of rice seed breeding was in the medium category $(41.1 \%)$. Community leaders in the farming community consist of village officials, religious leaders, and former government officials. Community leaders motivate farmers to follow technical instructions for the seed breeding process. Community leaders influence farmers' decision making. Community leaders had not been actively involved in assisting farmers and providing information on technology for the seed breeding business. Community leaders such as religious leaders, former officials, did not master the techniques of breeding rice seeds because they were not active in agriculture and had not played a role in facilitating collaboration opportunities with relevant stakeholders.

\subsection{The sustainability level of rice seed breeding business and its influencing factors}

The sustainability level of the rice seed breeding business at the aspect of market guarantee was in the medium category. The level of the aspect of production and business profits was in the high category (Table 3). The number of farmers' rice seed production increased compared to consumption rice production. Farmers applied government technology recommendations such as the planting system, the use of biodecomposers, and new varieties to increase production yields up to $19.97 \%$ compared to the existing varieties [29]. As much as $47.32 \%$ of farmers increased the area of paddy seed breeding land. Farmers feel the benefits of doing a rice seed breeding business.

In the aspect of market guarantee, as many as $42.0 \%$ of farmers assessed the sustainability level of the seed breeding business is in the medium category. The farmers' rice seed production was sold in that season. Extension officers facilitated the meetings of farm shops, farmer groups, and the private sector to establish cooperation. At the beginning of the planting period, farmers received information about the number of seeds needed by the 
private sector. Farmer groups shared the target for seed production fulfillment with members. Farmer groups only produced seeds according to the number of seed quote from cooperation partner's. When the farmers do not get market guarantees, they occasionally plant consumption rice. With the cooperation, the producers get the benefit of guaranteed seed availability, while breeder farmers get business capital assistance, cultivation guidance, and market guarantees [30].

Table 3. Comparison of the sustainability level of rice seed breeding in the three study sub-districts in Majalengka Regency, 2021

\begin{tabular}{|c|c|c|c|c|c|c|}
\hline \multirow{3}{*}{ Indicator } & \multirow{3}{*}{ Category } & \multicolumn{3}{|c|}{ Subdistrict } & \multirow{3}{*}{$\begin{array}{c}\text { Total } \\
\mathrm{n}=112\end{array}$} & \multirow{3}{*}{$\begin{array}{c}\text { Kruskal } \\
\text { Wallis } \\
\text { difference } \\
\text { test }\end{array}$} \\
\hline & & Jatitujuh & Kertajati & Sukahaji & & \\
\hline & & $\begin{array}{c}\mathrm{n}=48 \\
\%\end{array}$ & $\begin{array}{c}\mathrm{n}=34 \\
\%\end{array}$ & $\begin{array}{c}\mathrm{n}=30 \\
\%\end{array}$ & & \\
\hline \multirow{4}{*}{$\begin{array}{l}\text { Production aspect } \\
\text { (score) } \\
\text { Average }=79.17\end{array}$} & Very low & 0 & 2.9 & 0 & 0.9 & \multirow{4}{*}{$0.000^{* *}$} \\
\hline & Low & 2.1 & 29.4 & 26.7 & 17.0 & \\
\hline & Intermediate & 4.2 & 38.3 & 33.3 & 22.3 & \\
\hline & High & 93.7 & 29.4 & 40.0 & 59.8 & \\
\hline \multirow{4}{*}{$\begin{array}{l}\text { Market guarantee } \\
\text { aspect (score) } \\
\text { Average }=51.79\end{array}$} & Very low & 8.3 & 52.9 & 30.0 & 27.7 & \multirow{4}{*}{$0.001 * *$} \\
\hline & Low & 52.1 & 8.8 & 20.0 & 30.3 & \\
\hline & Intermediate & 39.6 & 38.2 & 50.0 & 42.0 & \\
\hline & High & 0 & 0 & 0 & 0 & \\
\hline \multirow{4}{*}{$\begin{array}{l}\text { Profit aspect } \\
\text { (score) } \\
\text { Average }=75.45\end{array}$} & Very low & 2.1 & 20.6 & 3.3 & 8.0 & \multirow{4}{*}{$0.000^{* *}$} \\
\hline & Low & 35.4 & 35.3 & 13.3 & 29.5 & \\
\hline & Intermediate & 2.1 & 17.6 & 33.4 & 15.2 & \\
\hline & High & 60.4 & 26.5 & 50.0 & 47.3 & \\
\hline
\end{tabular}

Note: Index score: very low $<25$; low 26-50; intermediate 51-75; high $>75$

$* *$ )Very significantly different at $<0.01$

In the aspect of business profits, $47.3 \%$ of farmers appraise the level of sustainability of the rice seed breeding business was in the high category. The seed breeding business required additional costs such as rouging costs, seed cleaning, seed testing, packaging and labeling. The average additional cost reaches IDR 10 million per ha. The increase in production costs was followed by higher seed price. The price of Extention Seed (ES) reaches IDR 9,000,- per $\mathrm{kg}$. Its higher than the price of consumption grain (IDR 5,000,- per $\mathrm{kg}$ ).

The rice seed breeding business had an $\mathrm{r} / \mathrm{c}$ value of 1.75 so it was feasible to cultivate and had good prospects for development. In one growing season the average profit per hectare of consumption farming is IDR 5 million -, the business of prospective rice seeds is IDR 10 million and the profit of the seed breeding business reaches IDR 15 million. This is confirmed by the results of research [31] who stated that the seed breeding business is profitable because the $\mathrm{r} / \mathrm{c}$ value is $>1$ and is higher than consumption rice farming.

\subsection{Factors influencing the rice seed breeding business sustainability}

The first-stage measurement model produced several variables that have a loading factor value of $<0.5$ so they must be excluded from the model [32]. The variables excluded were individual characteristics $\left(\mathrm{X}_{1}\right)$ : age, formal education, and land area; and level of community leader $\left(\mathrm{X}_{3}\right)$ : marketing. The measurement model after the invalid variables were excluded can be seen in Fig. 1. 


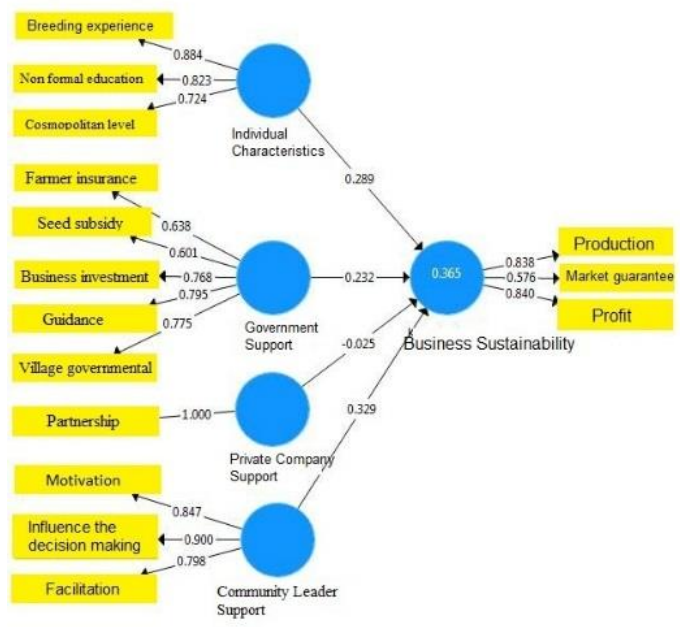

Fig. 1. Measurement model of factors influencing the sustainability level of the rice seed breeding business

The second iteration of the algorithm with the PLS analysis showed Average Variant Extracted $(\mathrm{AVE})>0.5$, discriminant validity and composite reliability $>0.7$. It indicated that the indicator was valid and reliable to reflect latent variables. The results of the structural model test showed the significance of the effect of each exogenous latent variable on the endogenous latent variable (Table 4). Latent variables that significantly affected the sustainability level of the rice seed breeding business were breeder characteristics, the level support of private companies and community leaders.

Table 4. Structural model test parameter value on factors influencing the sustainability level of seed breeding business

\begin{tabular}{|l|l|c|c|c|}
\hline $\begin{array}{l}\text { Endogenous latent } \\
\text { variable }\end{array}$ & Exogenous latent variable & Calculated-T & P-value & \multirow{2}{*}{$\mathrm{R}^{2}$} \\
\hline $\begin{array}{l}\text { Sustainability } \\
\text { level of Seed }\end{array}$ & Breeder characteristics & 5.249 & $0.031^{*}$ & \\
\cline { 2 - 4 } $\begin{array}{l}\text { Breeding } \\
\text { Business }\end{array}$ & Government support & 2.166 & 0.790 & \multirow{2}{*}{0.365} \\
\cline { 2 - 4 } & Private companies support & 0.267 & $0.000^{*}$ & \\
\cline { 2 - 4 } & Community leaders support & 3.883 & $0.000^{*}$ & \\
\hline
\end{tabular}

\subsubsection{Breeder characteristics}

Breeder characteristics that affect business sustainability were breeding experience, nonformal education, and cosmopolitan. This can be seen from the breeder characteristics of farmers in the Jati Tujuh sub-district who were better at having the highest level of sustainability among the three research locations.

Farmers who often attended non-formal education had the capability on choosing and applying effective and efficient technology for higher productivity. The results of breeding seed farming production were not inferior to consumption rice farming so that farmers' business profits can be obtained optimally. Non-formal education can be obtained through extension activities, field schools, training, and others [33].

Breeder farmers attended training on rice seed production systems, agricultural cultivation, rouging, pest control, and the used of agricultural machinery. Extension activities and good experience enabled farmers to implement the technology of breeding seed farming 
so that the amount of rice seed production increases and business profits were higher. During the breeding business, farmers plant rice with varieties and quantities according to the partner's request. Farmers knew the varieties favored by the market. Farmers sold seeds to various parties so the had more market access. According to [25] the longer the farmer manages a business, the stronger the incentive to be active in various discussions.

\subsubsection{Private companies support level}

Private companies support has a significant negative effect on the sustainability level of the rice seed breeding business. The farmers had difficulty in capital and marketing. Efforts to obtain business capital through people's business credit still need to be increased [34]. The facilitation of absorption of rice seed production by the government was also limited.

The farmers cooperated with the private companies in written or unwritten partnership. The private companies bought farmer's prospective seeds. The farmers did not had trademark of rice seed products. The farmers lose the potential profit of increasing the added value of rice seeds and limits farmers' marketing.

Some farmers ran unwritten partnership with private companies. They could stop the cooperation without any sanctions. The private companies stopped partnering because of high quality standards, the product was no longer needed, price and payment and limited capital [35]. Dependence on the private companies could threaten the sustainability of the rice seed breeding business.

\subsubsection{Community leaders support level}

Community leaders had a real influence on the sustainability of the rice seed breeding business. Community leaders were people who have the trust of the community and they could influence the behavior and decision-making of farmers in developing rice seed breeding business.

Community leaders such as religious leaders, traditional leaders and government employees were not directly involved in rice seed breeding business. They motivated the farmers for farming without providing technological information at farmers gruop's meetings. It was different from community leaders who act as farmer group leaders.

The head of the farmer group understands the technology of rice seed breeding business. They provided solutions to the breeder farmer's problems. They had relationships with the government and the private companies so that they could facilitate collaborations such as exhibitions, procurement of seeds for the seed subsidy programs.

\section{Conclusions}

The sustainability level of the rice seed breeding business in the aspect of market guarantee was in the medium category. The private companies can threaten the sustainability of the rice seed breeding business if cooperation with farmers does not aim to create farmer independence. Community leaders who are able to motivate and facilitate collaboration can influence farmers' decision making to continue their rice seed breeding. The research implies that the development of rice seed breeding business should encourage experienced farmers with a high degree of cosmopolitan, increase activities that support non-formal education and accessibility of information, involve community leaders to increase farmer motivation, influence farmer decision-making, and facilitate collaboration with other parties. The management of private companies support can benefit both parties and it does not cause dependence on breeder farmers. 


\section{References}

1. Riefqi, A. R., Surahman, M. \& Hastuti . Buletin Agrohorti 5, 1-8 (2017).

2. Yuliani, D., Wage, D. \& Rohaeni, R. Jurnal Litbang Pertanian 36, 99-108 (2017).

3. Direktorat Perbenihan Tanaman Pangan. Laporan Tahunan Direktorat Perbenihan Tanaman Pangan Tahun 2019. Direktorat Jenderal Tanaman Pangan (2020).

4. Dinas Tanaman Pangan dan Hortikultura. Programa Penyuluhan Pertanian Provinsi Jawa Barat Tahun 2020. (2020).

5. Nuswardhani, S. K. \& Arief, B. Agrika 13, 162 (2019).

6. Supriatna, A. \& Dhalimi, A. Jurnal Pengkajian dan Pengembangan Teknologi Pertanian 13, 29-41 (2010).

7. Sayaka, B. Analisis Kebijakan Pertanian 13, 185-202 (2015).

8. Ristianingrum, A., Chozin, M. A., Machfud, M., Sugiyanta, S. \& Mulatsih, S. Jurnal Manajemen dan Agribisnis 13, 37-49 (2016).

9. Yunianti, A. \& Fauziyah, E. SEPA: Jurnal Sosial Ekonomi Pertanian dan Agribisnis 11, 163-174 (2015).

10. Saida, S., Sabiham, S., Widiatmaka, W. \& Sutjahjo, S. H. Jurnal Matematika Sains dan Teknologi 12, 101-112 (2011).

11. Bahari, B., Saediman, H., Geo, L. \& Arif, N. International Journal of Economics and Financial Issues 9, 142-150 (2019).

12. Chambers, R. Challenging the Profession: Frontiers for rural development. (Intermediate Technology Publications, 1993).

13. Pavlovskaia, E. Environmental Sciences Europe 26, 1-12 (2014).

14. Sapukotanage, S., Warnakulasuriya, B. N. F. \& Yapa, S. T. W. S. International Business Research 11, 89 (2018).

15. Leasa, W. B., Amanah, S. \& Fatchiya, A. Jurnal Penyuluhan 14, 20-35 (2018).

16. Saeed, M. A. \& Kersten, W. Logistics Research 10, (2017).

17. Suryani, A., Suryani, A., Fatchiya, A. \& Susanto, D. Jurnal Penyuluhan 13, 50-63 (2017).

18. Laksmi, N. M. A. C., Windia, W. \& Suamba, K. Jurnal Manajemen Agribisnis (Journal Of Agribusiness Management) 5, 22-32 (2017).

19. Rahmawati, N. \& Triyono, T. AGRARIS: Journal of Agribusiness and Rural Development Research 3, 128-137 (2017).

20. Mita, Y. T., Haryono, D. \& Marlina, L. Jurnal Ilmu-ilmu Agribisnis 6, 125-132 (2018).

21. Mundiyah, A. I. \& Tahir, R. Agroland:The Agriculture Science Journal 6, 107-117 (2019).

22. Ulpah, A., Tinaprilla, N. \& Mohammad Baga, L. Jurnal Pengkajian dan Pengembangan Teknologi Pertanian 21, 259-275 (2018).

23. Ghosali, H. \& Latan. Partial Least Square: Konsep, Teknik dan Aplikasi menggunakan Smart PLS 3.0. (UNDIP, 2015).

24. Herawati, H., Hubeis, A. V., Amanah, S. \& Fatchiya, A. Jurnal Pengkajian dan Pengembangan Teknologi Pertanian 20, 155 (2017).

25. Lestari, N., Amanah, S., Muljono, P. \& Susanto, D. AGRARIS: Journal of Agribusiness and Rural Development Research 5(1), 66-78 (2019).

26. Rogers, E. \& Shoemaker, F. Communication of Innovation: A Cross Cultural Approach. (Collier Macmillam Publish, 1995).

27. Wahyuningsih, T. Am. \& Hasan, F. Jurnal Sosial Ekonomi Pertanian 12, 11-21 (2019).

28. Asiati, D. \& Nawawi, N. Jurnal Kependudukan Indonesia 11, 103-118 (2016).

29. Chairiyah, R., Manurung, E., Jonharnas \& Syahnur, H. Jurnal Pengkajian dan Pengembangan Teknologi Pertanian 23, 151-159 (2020).

30. Darwis, V. SAnalisis Kebijakan Pertanian 16, 59-72 (2018). 
31. Wachdijono. Paradigma Agribisnis 2, 43-53 (2019).

32. Vinci, V. E., Chin, W. W., Henseler \& J Wang, H. Handbook of Partial Least Square. Concepts, Methods and Aplication. (Springer-Verlag Berlin, 2010).

33. Amanah, S. Paradigma Penyuluhan dan Pendekatan Pemberdaayaan. Di dalam: Pemberdayaan sosial Petani-nelayan, Keunikan Agroekosistem dan daya saing. (Yayasan Pustaka Obor Indonesia, 2014).

34. Dwirayani, D. \& Jaeroni, A. Jurnal Ekonomi Pertanian dan Agribisnis (JEPA) 4, 808815 (2020).

35. Purnaningsih, N. Sodality:Jurnal Transdisiplin Sosiologi, Komunikasi dan Ekologi Manusia 01, 393-416 (2007). 